\title{
Strategi Pengembangan Portofolio Bisnis PT Kawasan Berikat Nusantara (Persero)
}

\author{
Development Strategy of Business Porfolio in PT Kawasan Berikat Nusantara (Persero)
}

\author{
Dony Ariya Iskandar ${ }^{{ }^{*}}$, Lukman Mohammad Baga ${ }^{2 \sharp}$, dan Imam Teguh Saptono ${ }^{3 \#}$ \\ ${ }^{1}$ Magister Manajemen dan Bisnis, Sekolah Bisnis Pascasarjana Institut Pertanian Bogor \\ \#Jl. Raya Pajajaran, Kampus IPB Gunung Gede Bogor 16151
}

\begin{abstract}
ABSTRAK
Tujuan penelitian untuk menganalisis strategi pengembangan portofolio bisnis di PT Kawasan Berikat Nusantara (KBN). Penelitian menggunakan metode deskriptif dengan alat analisis yang digunakan antara lain Internal Factor Evaluation (IFE). External Factor Evaluation (EFE), Matriks Grand Strategy, dan Matriks General Electric (GE). Berdasarkan analisis Matriks Grand Strategy, hasil IFE dan EFE menunjukkan bahwa posisi perusahaan berada pada kuadran I. Rekomendasi strategi yang diperoleh dari kuadran ini adalah strategi pertumbuhan (Growth Strategy), dengan implikasi program kerja meliputi pengembangan dan penetrasi pasar, pengembangan produk, melakukan integrasi horisontal, ke depan, dan ke belakang. Selain itu pilihan strategi yang dapat diterapkan adalah melakukan diversifikasi produk secara terpusat. Hasil analisis Matriks GE menunjukkan bahwa empat unit bisnis perusahaan yakni jasa properti, prima beton, pengelolaan air bersih dan jasa logistik masing-masing berada pada kuadran berbeda. Jasa Properti dan Prima Beton berada pada sel selektif. Dalam hal ini, unit bisnis pengelolaan air bersih dan jasa logistik berada pada sel divestasi. Berdasarkan rekomendasi Matriks Grand Strategy, masing-masing unit bisnis sebaiknya meningkatkan kinerjanya dalam lima tahun mendatang melalui strategi pertumbuhan yang lebih selektif, yakni pengembangan produk dan pasar yang lebih selektif, peningkatan mutu dan kuantitas sumber daya manusia, dan melakukan investasi yang diprioritaskan pada unit bisnis yang memiliki pertumbuhan cepat.
\end{abstract}

Kata kunci: EFE, GE Matrix, IFE, kawasan berikat nusantara, portfolio bisnis

\section{ABSTRACT}

The research objective is to analyze the business portfolio development strategy at PT. Kawasan Berikat Nusantara (KBN). The study used descriptive method with the analytical tools used, among others, Internal Factor Evaluation (IFE). External Factor Evaluation (EFE), Grand Strategy Matrix, and General Electric (GE) Matrix. Based on the analysis of the Grand Strategy Matrix, the results of IFE and EFE indicate that the position of the company is in quadrant I. The strategy recommendations obtained from this quadrant are the growth strategy (Growth Strategy), with the implications of work programs including market development and penetration, product development, horizontal integration, forwards, and backwards. Besides that, the choice of strategy that can be applied is to diversify products centrally. The results of the GE Matrix analysis show that the company's four business units namely property services, prime concrete, clean water management and logistics services are each in a different quadrant. Property Services and Prima Concrete are in selective cells. In this case, the business unit for clean water management and logistics services is in the divestment cell. Based on the recommendations of the Grand Strategy Matrix, each business unit should improve its performance in the next five years through a more selective growth strategy, namely the development of more selective products and markets, improving the quality and quantity of human resources, and prioritizing investments in business units who have fast growth.

Key words: business portfolio, EFE, GE Matrix, IFE, kawasan berikat nusantara

\footnotetext{
*) Korespondensi:

Mutiara Bogor Raya, zona Sevilla blok C2 No. 6 Katulampa, Bogor 16144; email: donyariya@gmail.com; Hp: 0818699394
} 


\section{PENDAHULUAN}

Perekonomian memiliki peran penting seba-gai salah satu indikator kemajuan suatu negara. Namun, laju pertumbuhan ekonomi dapat dipengaruhi oleh kondisi perekonomian global. Saat ini, perekonomian dunia sedang mengalami penurunan merupakan dampak dari melemahnya permintaan pasar yang karenaharga komoditi belum pulih. Hal ini menyebabkan pertumbuhan ekonomi dunia cenderung rapuh dan sering bergejolak sejak beberapa tahun terakhir.

Menteri Keuangan Indonesia, Sri Mulyani menjelaskan bahwa pertumbuhan perekonomian dunia pada tahun 2017 hanya berada pada level 3,4\% (Sindonews.com, 2017). Menurutnya, harga komodi-tas yang belum pulih menjadi salah satu penyebab lemahnya perekonomian Indonesia. Lemahnya ekonomi global memberikan tekanan yang berdampak pada fluktuasi kinerja ekspor impor Indonesia. Persentase nilai ekspor Indonesia selama tahun 2012-2016 terus mengalami penurunan seperti terlihat pada Gambar 1.

Penurunan ekspor sejumlah produk Indonesia merupakan akibat dari resesi dunia. Beberapa produk yang terkena imbas seperti tekstil, garmen, mebel, alas kaki dan lainnya. Garmen merupakan salah satu komoditas ekspor non migas yang memiliki pasar cukup luas. Di Indonesia, industri garmen banyak ditemukan di kawasan berikat, yakni sebuah kawasan yang diberikan pemerintah dengan fasilitas bidang kepabean dan cukai. Kawasan ini dibuat pemerintah untuk meningkatkan daya saing produk dalam negeri terhadap produk-produk internasional.

Kelangsungan usaha sebuah perusahaan kawasan berikat dapat mudah dilihat dari kagiatan ekspor produknya. Namun, saat ini banyak perusahaan pengguna fasilitas kawasan berikat yang terancam keberlangsungannya sebagai akibat dari adanya krisis global. Pada tahun 2009 sebanyak 4.034 orang karyawan di kawasan berikat meng-alami pengurangan. Kasus ini kemudian terulang pada tahun 2015, dimana 5.300 orang karyawan di PT KBN (Persero) mengalami pemutusan kerja. Pemutusan kerja tersebut umumnya terjadi karena perusahaan mengalami kebangkrutan sehingga tidak bisa menutup biaya operasional.

PT KBN (Persero) merupakan salah satu kawasan industri garmen terbesar di Indonesia yang menghasilkan berbagai macam produk untuk tujuan ekspor. Usaha pokok KBN adalah mengelola kawasan industri terpadu berstatus berikat yang berfungsi sebagai kawasan proses ekspor (export processing zone atau EPZ) dan nonberikat, serta jasa pelayanan logistik yang meliputi usaha angkutan, mekanik dan dokumen (forwarding), dan pergudangan (warehousing). Dua bisnis utama yang dijalankan PT KBN terdiri atas jasa properti dan pelayanan logistik.

Guncangan perekonomian global, yang memengaruhi perubahan landscape dunia bisnis, menuntut KBN cepat beradaptasi agar mampu bertahan dan terus mengembangkan bisnisnya. Sebagai perusahaan senior yang telah berdiri sejak tahun 1986, KBN telah melakukan perjuangan panjang dalam menghadapi tantangan perubahan dunia bisnis. Saat ini, KBN melakukan pengelolaan kawasan industri multi purpose yang terintegrasi (seperti pelabuhan), berwawasan lingkungan dan bertaraf internasional. Dengan usaha tersebut perusahaan berharap mampu segera memperbaiki kondisi bisnis. Namun, bila dilihat dari kinerja keuangan perusahaan (PT KBN, 2016), pendapaan perusahaan menunjukkan tren penurunan selama lima tahun terakhir (2012-2016).

Penurunan kinerja keuangan KBN menjadi sebuah indikator sekaligus warning agar perusahaan segera membuat terobosan strategi untuk meningkatkan "gairah" bisnisnya. Salah satu cara untuk mengembangkan strategi bisnis perusahaan adalah menggunakan portofolio bisnis (Cooper et al., 2000). Portofolio bisnis menurut Lukito et al., (2013), merupakan alat analisis bisnis yang dapat digunakan untuk menganalisis kinerja setiap unit bisnis/ produk dan keterkaitannya dengan semua unit bisnis/ produk dalam perusahaan. Portofolio bisnis juga dirancang untuk merumuskan strategi yang konsisten pada perusahaan besar yang memiliki banyak unit bisnis dan memiliki sejumlah tingkatan strategi bisnis yang berbeda sehingga perlu diatur untuk mencapai tujuan perusahaan secara seimbang dan berkelanjutan.

Tujuan penelitian merumuskan strategi pengembangan portofolio bisnis $\mathrm{KBN}$ melalui analisis faktor internal dan eksternal perusahaan, analisis gap dan analisis kondisi perusahaan berdasarkan Matriks Grand Strategy dan Matriks General Electric (GE).

\section{METODE PENELITIAN}

Penelitian ini dilaksanakan di PT KBN (Persero), yang beralamat di Jl. Raya Cakung Cilincing, Tanjung Priok, Jakarta. Waktu penelitan adalah pada bulan Januari-April 2018. Penelitian 


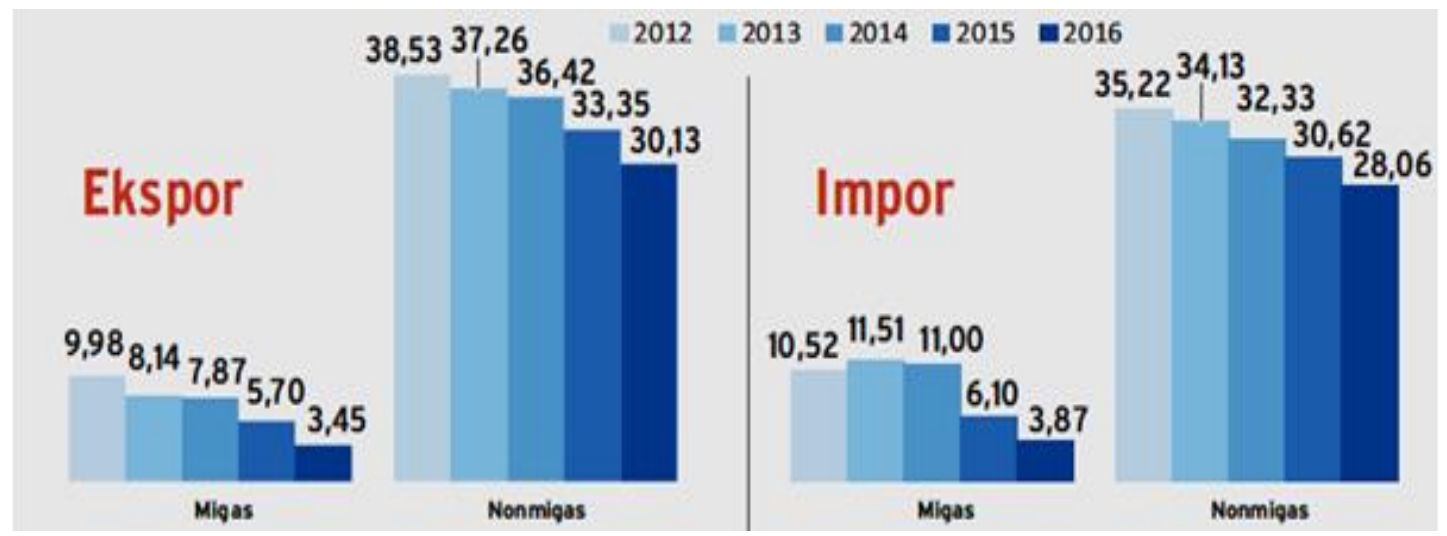

Gambar 1. Perkembangan ekspor-impor produk migas dan non migas

ini menggunakan metode deskriptif. Jenis data yang digunakan berupa data primer dan sekunder yang dikumpulkan melalui metode observasi, wawancara, kuesioner dan studi literatur. Responden penelitian terdiri dari manajemen PT KBN, praktisi dan kalangan akademisi (peneliti/ pengamat/konsultan) dengan pemilihan purposive.

Tahap pengolahan dan analisis data yang dilakukan meliputi identifikasi faktor-faktor yang memengaruhi bisnis perusahaan dari sisi internal dan eksternal dengan metode Internal Factor Evaluation (IFE) dan External Factor Evaluation (EFE), analisis kesenjangan (gap analysis), dan analisis portofolio bisnis dengan metode Grand Strategy Matrix dan GE Matrix.

\section{HASIL DAN PEMBAHASAN}

\section{Visi, Misi dan Arah Pengembangan PT KBN}

Kebijakan penyusunan visi dan misi KBN dilakukan atas dasar kesepakatan jajaran manajemen yang dihasilkan melalui rapat berkala setiap tahun (annual meeting). Priyanto (2016) menyatakan visi merupakan kalimat yang menyatakan cita-cita atau impian sebuah organisasi yang ingin dicapai dimasa depan. Hasil Focus Group Discussion (FGD) dengan jajaran Manajemen KBN memerlihatkan bahwa kebijakan visi, misi dan arah pengembangan perusahaan memiliki tingkat pemahaman yang cenderung rendah. Sebagian peserta menyatakan tidak setuju bila pemahaman terhadap visi, misi dan arah pengembangan bisnis perusahaan telah dipahami secara menyeluruh pada semua lapisan karyawan. Sebagian besar peserta menyatakan bahwa visi, misi dan arah pengembangan bisnis yang dinginkan oleh pimpinan kurang disampaikan secara jelas, terperinci dan mudah dipahami oleh seluruh lapisan. Hal ini menjadi bahan masukan yang berharga bagi direksi dan manajemen untuk melakukan perbaikan proses pembentukan visi, misi dan arah kebijakan, serta pelaksanaan sosialisasi yang menyeluruh pada seluruh lapisan karyawan. Disisi lain, sebagian besar peserta pernyataan Visi, Misi dan Arah Pengembangan masih sesuai dengan lingkungan bisnis yang dihadapi KBN. Pernyataan visi perusahaan tersebut adalah "Pengelolaan kawasan industri multi purpose yang terintegrasi dengan pelabuhan, berwawasan lingkungan dan bertaraf internasional".

\section{Analisis Lingkungan Eksternal}

Lingkungan ekstenal perusahaan dapat dikategorikan menjadi dua, yakni lingkungan makro dan lingkungan industri. Menurut Pantjadhama (2015), perusahaan harus mampu mengumpulkan dan menganalisis informasi secara detail mengenai perkiraan strategi pesaing dan perubahan pasar untuk menjadi unggul di dalam persaingan yang dinamis.

Hasil analisis menyimpulkan faktor strategik yang mendapatkan skor tertinggi untuk pengembangan bisnis KBN, yakni (1) adanya permintaan kebutuhan yang tinggi pada pelabuhan, terminal bongkar muat peti kemas dan darmaga bahan-bahan curah di Jakarta $(0,333) ;(2)$ lokasi KBN yang berdekatan dengan Rumah Susun Marunda memberikan akses atas banyaknya tenaga kerja potensial $(0,278)$; dan (3) ketersediaan landbank untuk better use yang lain $(0,269)$. Ketiga faktor tersebut manjadi peluang pengembangan bisnis KBN sebagai daya tarik industri pada investor.

Tiga faktor strategi lainnya yang mendapat skor terendah atau menjadi ancaman bagi KBN adalah (1) ketidakpastian dalam regulasi pemerintah $(0,063)$; (2) masalah (clean $\mathcal{E}$ clear) aspek hukum berkenaan dengan hak kepemilikan tanah di wilayah Marunda $(0,067)$, dan dua faktor ke-3 
yang memiliki skor yang sama 0,130 adalah adanya kemacetan dan keterbatasan infrastruktur transportasi di daerah Jabodetabek yang menyebabkan tingginya biaya logistik dan tingginya UMP Jakarta yang berpotensi pada relokasi investasi ke daerah lain. Penilaian hasil identifikasi eksternal dapat dilihat pada Tabel 1.

\section{Analisis Lingkungan Internal}

Saat ini KBN tercatat memiliki lahan seluas 571,5 ha. Wilayah usaha KBN terletak di wilayah Jakarta Utara dan terbagi menjadi tiga lokasi, yaitu Cakung, Marunda dan Tanjung Priok. Fasilitas, komposisi dan luasan setiap kawasan berikat dan kawasan non berikat untuk masingmasing lokasi berbeda-beda. Meskipun tercatat memiliki lahan seluas 571,5 ha, namun dengan banyaknya kasus hukum terkait kepemilikan lahan KBN oleh para investor. Lahan yang saat ini dikuasai KBN hanya mencapai sekitar 60 ha. Berdasarkan hasil analisis internal disimpulkan bahwa tiga faktor kekuatan strategik dengan skor tertinggi yang dimiliki KBN adalah (1) posisi landbank yang strategis di Jakarta (dekat dengan pelabuhan tanjung priok dan akses tol) $(0,288) ;(2)$ memiliki cadangan lahan di pinggir pantai Teluk Jakarta untuk mengembangkan usaha/industri dan pelabuhan umum $(0,288)$; dan (3) lokasi dekat dengan perairan (pantai), sehingga menjadi daya tarik pada perusahaan yang membutuhkan moda transportasi intra/interinsuler pengangkutan barang $(0,278)$. Tiga faktor kelemahan strategik yang dimiliki perusahaan adalah (1) nilai (sharevalue) yang selaras dengan strategi belum menjadi budaya kerja keseluruhan karyawan $\operatorname{KBN}(0,049)$; (2) banyaknya kontrak sewa dengan tarif rendah dan waktu yang panjang $(0,050)$; dan (3) KBN tidak memiliki fleksibilitas untuk melakukan optimasi lahan yang dimiliki, karena terdapat beberapa perjanjian terdahulu yang relatif mengikat antara KBN dengan investor (terutama terkait dengan perpanjangan penggunaan tanah industri atau PPTI) $(0,060)$. Hasil analisis menggunakan matriks IFE secara lebih detail terlihat pada Tabel 2 .

Tabel 1. Identifikasi peluang dan ancaman PT KBN (Persero)

\begin{tabular}{|c|c|c|c|c|c|}
\hline No. & Faktor Strategis Eksternal & Status & Bobot & Rating & Skor \\
\hline 1 & Memiliki captive market untuk melakukan diversifikasi usaha. & Peluang & 0,074 & 3 & 0,222 \\
\hline 2 & $\begin{array}{l}\text { Lokasi yang dekat dengan Rumah Susun Marunda memberikan akses } \\
\text { atas banyaknya tenaga kerja potensial. }\end{array}$ & Peluang & 0,093 & 3 & 0,278 \\
\hline 3 & $\begin{array}{l}\text { Permintaan kebutuhan yang tinggi atas pelabuhan baru, terminal } \\
\text { bongkar muat peti kemas, dan dermaga bahan-bahan curah di Jakarta. }\end{array}$ & Peluang & 0,083 & 4 & 0,333 \\
\hline 4 & $\begin{array}{l}\text { Permintaan lahan industri di Pulau Jawa cukup tinggi, tetapi } \\
\text { ketersediaan lahan yang siap pakai terbatas. }\end{array}$ & Peluang & 0,058 & 4 & 0,231 \\
\hline 5 & $\begin{array}{l}\text { Tingginya traffic pada jalur Pantura menjadi potensi tingginya usaha } \\
\text { coastal shipping. }\end{array}$ & Peluang & 0,088 & 3 & 0,264 \\
\hline 6 & $\begin{array}{l}\text { Usaha properti non kawasan industri memiliki potensi pertumbuhan } \\
\text { tinggi. }\end{array}$ & Peluang & 0,076 & 3 & 0,229 \\
\hline 7 & $\begin{array}{l}\text { Daya tarik pertumbuhan dan profitabilitas industri lainnya yang dimuat } \\
\text { dalam Anggaran Dasar baru perusahaan menjanjikan growth engine baru } \\
\text { bagi perusahaan. }\end{array}$ & Peluang & 0,056 & 3 & 0,167 \\
\hline 8 & $\begin{array}{l}\text { Meningkatnya arus barang impor dalam era globalisasi memungkinkan } \\
\text { pengembangan kegiatan angkutan \& pergudangan sebagai bagian dari } \\
\text { mata rantai Total Logistic System. }\end{array}$ & Peluang & 0,079 & 3 & 0,236 \\
\hline 9 & Ketersediaan landbank dapat digunakan untuk better use yang lain. & Peluang & 0,067 & 4 & 0,269 \\
\hline 10 & $\begin{array}{l}\text { Tingginya UPM Jakarta berpotensi investor PT KBN melakukan relokasi } \\
\text { ke daerah lain. }\end{array}$ & Ancaman & 0,065 & 2 & 0,13 \\
\hline 11 & $\begin{array}{l}\text { Kemacetan dan keterbatasan infrastruktur transportasi di daerah } \\
\text { Jabodetabek menyebabkan tingginya biaya logistik. }\end{array}$ & Ancaman & 0,065 & 2 & 0,13 \\
\hline 12 & $\begin{array}{l}\text { Proses Birokrasi perusahaan BUMN relatif rumit untuk melakukan } \\
\text { ekspansi ataupun diversifikasi usaha. }\end{array}$ & Ancaman & 0,067 & 2 & 0,134 \\
\hline 13 & $\begin{array}{l}\text { Masalah (clean } \mathcal{E} \text { clear) aspek hukum berkenaan dengan hak milik tanah } \\
\text { di Marunda. }\end{array}$ & Ancaman & 0,067 & 1 & 0,067 \\
\hline 14 & Ketidakpastian regulasi dan birokrasi. & Ancaman & 0,063 & 1 & 0,063 \\
\hline \multicolumn{2}{|r|}{ TOTAL } & & 1,000 & & 2,752 \\
\hline
\end{tabular}




\section{Gap Analysis dan Posisi Perusahaan}

Menurut Kahveci dan Meads (2008), kesenjangan (gap) dapat dianalisis untuk melihat kondisi perusahaan dalam menghadapi persaingan. Analisis kesenjangan dilakukan melalui kajian kesenjangan antara kinerja KBN (kondisi aktual) dengan Rencana Jangka Panjang Perusahaan (RJPP) yang telah dibuat pada tahuntahun sebelumnya. Penilaian kinerja merupakan penentuan secara periodik efektivitas operasional suatu organisasi (Mulyadi, 2009). Hasil penilaian dapat digunakan sebagai umpan balik yang memberikan informasi tentang prestasi pelaksanaan suatu rencana serta penyesuaian yang perlu dilakukan perusahaan atas perencanaan dan pengendalian (Yuwono et al., 2007). Dengan demikian, penilaian kinerja dapat dilakukan untuk memerbaiki kinerja perusahaan yang telah berlangsung untuk mendorong peningkatan efisiensi dan daya saing (Iswahyudi et al., 2016).

Pada tahun 2012, beban pokok yang lebih rendah dari rencana menyebabkan laba bruto diatas RJPP 22\%. Namun, tingginya beban usaha dan beban lain-lain membuat laba tahun berjalan lebih rendah dari RJPP 14\%. Tahun 2013 nominal realisasi jauh melebihi RJPP dengan pendapatan mencapai lebih dari $60 \%$ rencana yang menyebabkan laba bruto melonjak $125 \%$ atau lebih dari 2 kali lipat RJPP. Pada tahun 2014, nominal realisasi meningkat lebih dari 10\% dibandingkan RJPP tahun 2013. Pendapatan melebihi 52\% dari rencana yang menyebabkan laba bruto melonjak 99\% atau hampir 2 kali lipat dari RJPP. Tahun 2015, pendapatan meningkat hampir 3 kali lipat, sementara laba tahun berjalan naik 6 kali lipat dibandingkan RJPP tahun 2014. Realisasi penda-

Tabel 2. Identifikasi kekuatan dan kelemahan PT KBN

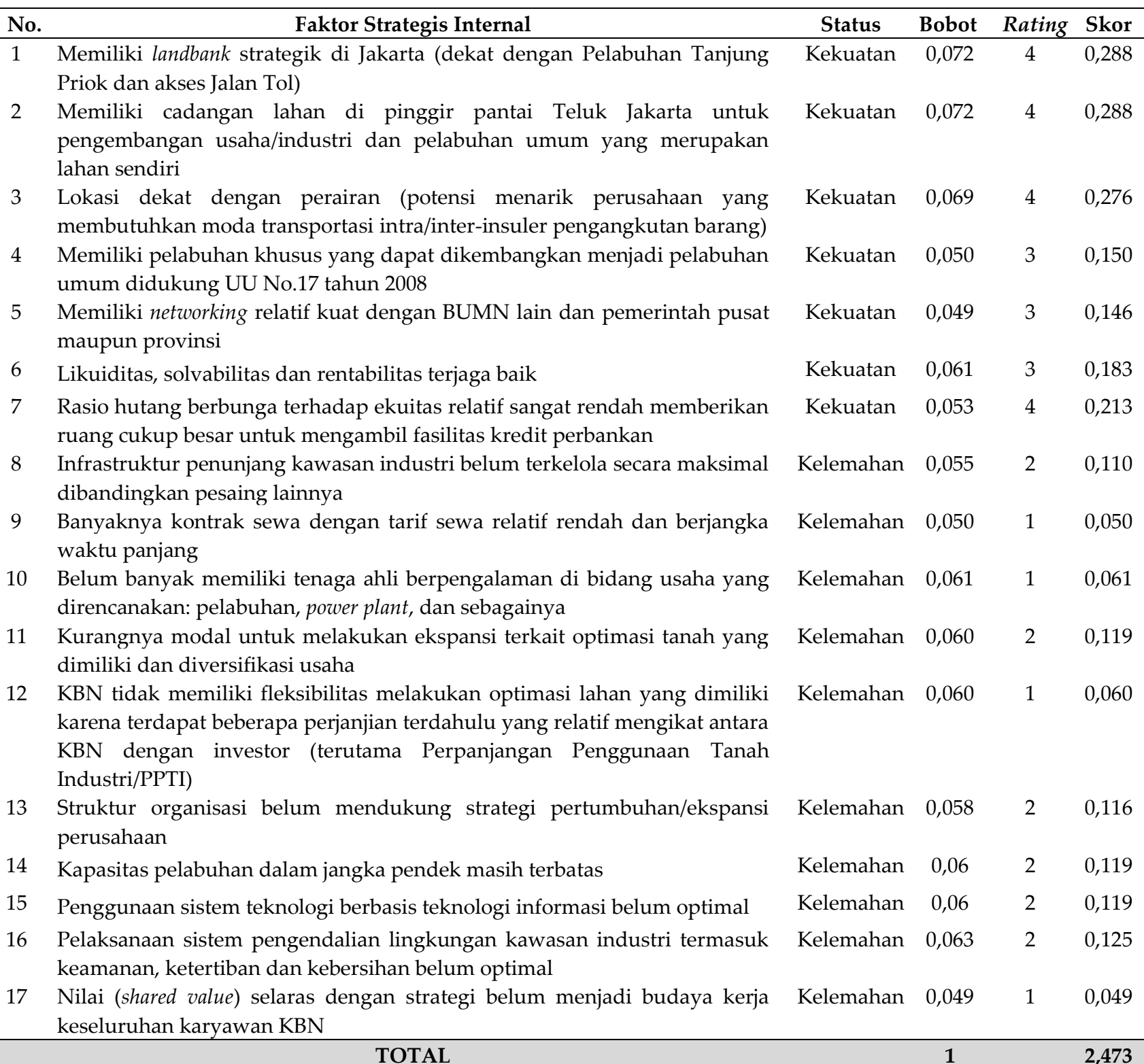


patan hanya $56 \%$ dari rencana yang menyebabkan laba bruto menurun sebesar $36 \%$ dari RJPP. Jauhnya pencapaian ini menyebabkan laba tahun berjalan pada tahun 2015 hanya sebesar 15\% dibandingkan RJPP. Jauhnya pencapaian realisasi tahun 2015 membuat Rencana Kerja dan Anggaran Perusahaan (RKAP) 2016 yang disusun sebagai pengganti RJPP diturunkan secara signifikan. Mulai dari pendapatan turun $50 \%$, laba bruto turun $50 \%$, hingga laba tahun berjalan diturunkan sampai $30 \%$. Realisasi pendapatan mencapai $99 \%$ dari rencana yang menyebabkan laba bruto mencapai $93 \%$ dari RJPP. Adanya tambahan pendapatan lain-lain, membuat laba tahun berjalan tahun 2016 lebih besar 4,4\% dibandingkan dengan RJPP.

Berdasarkan hasil analisis EFE 2,752 dan IFE sebesar 2,473, maka posisi perusahaan berada pada Kuadran Imenurut Grand Strategy Matrix. Posisi perusahaan pada kuadran I memerlihatkan laju pertumbuhan pasar cukup tinggi dan persaingan cukup kuat (Sampor et al., 2017). Faktor kekuatan yang paling dominan saat ini adalah ketersediaan landbank di Jabodetabek dengan lokasi strategik, sedangkan kelemahan yang paling dominan terletak pada faktor struktur organisasi saat ini yang belum selaras dengan strategi perusahaan, dan keterbatasan SDM dengan kompetensi terkait bisnis-bisnis baru yang ingin dijalankan. Faktor peluang yang paling dominan adalah potensi industri lain yang telah dimuat dalam Anggaran Dasar baru yang menjanjikan growth engine baru bagi perusahaan; sedangkan ancaman paling dominan terletak pada aspek legalitas pada sebagian lahan yang dimiliki KBN.

Berdasarkan analisis kondisi dan kinerja perusahaan yang ada, maka lima tahun mendatang KBN sebaiknya merencanakan kegiatan usaha dengan strategi pertumbuhan (growth strategy) yang didahului dengan penguatan internal. Untuk itu KBN harus segera mengatasi berbagai kelemahan yang dimiliki, terutama pada kelemahan paling dominan yang mengekang pertumbuhan perusahaan, terletak pada faktor struktur organisasi saat ini, tidak selaras dengan strategi pengembangan perusahaan dan SDM dengan kompetensi terkait bisnis-bisnis baru yang diinginkan belum tersedia. Kelemahan-kelemahan ini harus segera diatasi dalam jangka pendek, yaitu tahun pertama dari periode lima tahun RJPP dankemudian dilanjutkan dengan penyempurnaan pada semester dua. Setelah berbagai kelemahan tersebut teratasi dengan baik, PT KBN memiliki fondasi kokoh untuk melakukan rapid growth. Bila perusahaan dapat mengimplementasikan strategi tersebut maka sepanjang lima tahun mendatang posisi perusahaan akan tetap berada pada Kuadran I, dengan nilai EFE dan IFE yang terus bertambah besar seperti terlihat pada Gambar 2. Untuk mencapai hal tersebut, pelaksanaan strategi harus didukung dengan evaluasi pada setiap prosesnya (Pearce dan Robinson, 2014).

\section{Portofolio Unit Bisnis PT KBN}

Saat ini KBN memiliki 4 empat lini bisnis utama yang berkontribusi pada pendapatan perusahaan. Persentase kontribusi laba dari masing-masing lini bisnis adalah $46 \%$ dari penyewaan properti untuk industri, $20 \%$ dari layanan logistik, 30\% dari pengelolaan air bersih dan $4 \%$ dari jasa prima beton. Hasil perhitungan dari analisis masing-masing unit bisnis diperoleh Daya Tarik Industri (DTI) dan Kekuatan Unit Bisnis (KUB) pada kondisi saat ini dan masa mendatang menunjukkan adanya perbedaan. seperti pada Tabel 3.

Tabel 3. Nilai daya tarik industri dan kekuatan unit bisnis PT KBN

\begin{tabular}{clcccc}
\hline \multirow{2}{*}{ No } & \multirow{2}{*}{ Unit bisnis } & \multicolumn{2}{c}{ Kondisi saat ini } & \multicolumn{2}{c}{ Kondisi mendatang } \\
\cline { 3 - 5 } & & DTI & KUB & DTI & KUB \\
\hline 1 & Penyewaan properti & 2,276 & 2,125 & 3,037 & 3,244 \\
2 & Layanan logistik & 1,886 & 1,694 & 2,530 & 2,794 \\
3 & Pengelolaan air bersih & 1,799 & 2,019 & 2,403 & 2,713 \\
4 & Prima beton & 2,235 & 2,010 & 2,434 & 2,704 \\
\hline
\end{tabular}




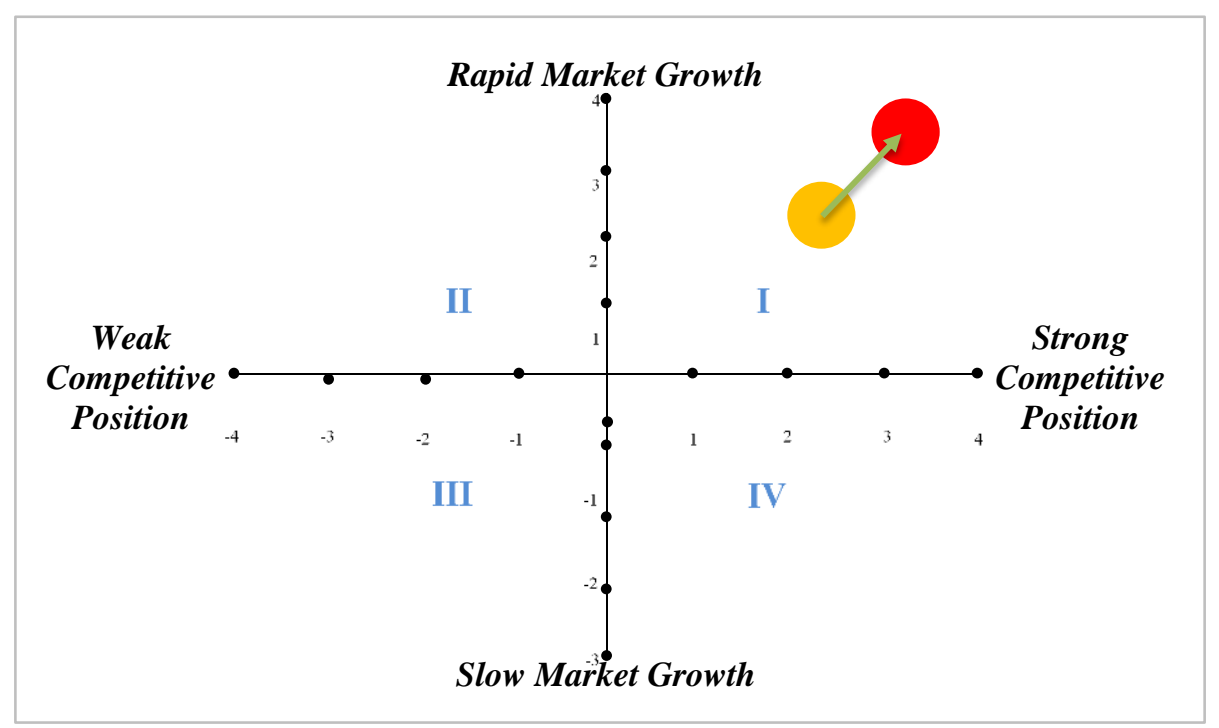

Gambar 2. The Grand Strategy Matrix PT KBN

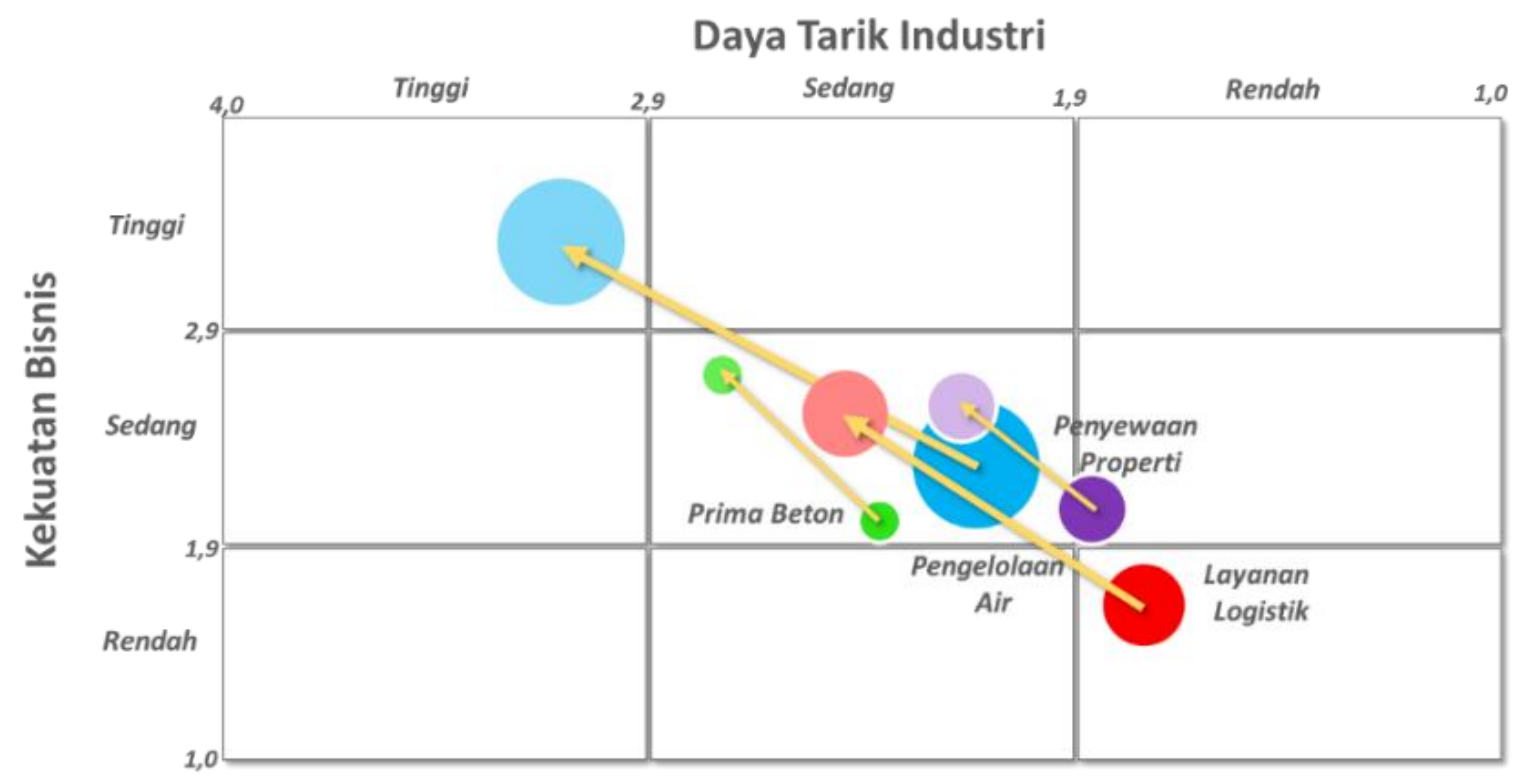

Gambar 3. Daya tarik industri dan daya saing unit bisnis PT KBN

Wahyuandari (2013) mengungkapkan bahwa product life cycle sangat erat kaitanya dengan kondisi bisnis yang terlihat pada matriks GE. Berdasarkan hasil penilaian tersebut maka gambaran portofolio masing-masing unit bisnis KBN dapat digambarkan pada matriks GE yang dimuat pada Gambar 3. Pemetaan pada gambar tersebut memperlihatkan keempat unit bisnis utama KBN terdapat dua unit bisnis berada pada kondisi Selective-kuadran III, yakni unit bisnis pengelolaan properti dan jasa prima beton. Dua unit bisnis lainnya, yakni pengelolaan air dan layanan logistik dalam kondisi divestasi (kuadran IV). Kondisi ini menunjukan bahwa struktur industri kedua unit bisnis tersebut kurang menguntungkan. Dalam lima tahun mendatang, KBN harus bertumbuh melalui berbagai upaya perluasan pasar dan perluasan produk/layanan berdasarkan analisis portofolio bisnis, dengan memanfaatkan sumberdaya yang berlebih guna meraih peluang jangka pendek, jangka menengah maupun jangka panjang, yang dapat dilakukannya secara sendiri maupun dengan membangun kemitraan/aliansi strategik dengan pihak lain atau mendirikan anak perusahaan. Selain pertumbuhan pendapatan, pertumbuhan aset juga harus menjadi perhatian utama, yang pada akhirnya mampu meningkatkan nilai perusahaan (Piorita et al. 2018). Untuk merealisasikan hal tersebut, perlu dilakukan penyusunan perencanaan program strategik guna perbaikan dan partumbuhan perusahaan selama 5 tahun mendatang. Iacob et al. (2012) menambahkan bahwa penerapan strategi yang efektif dalam matriks GE perlu 
dilakukan secara intensif dan integratif untuk mencapai kesuksesan organik.

\section{KESIMPULAN}

Berdasarkan hasil analisis grand strategy matrix posisi perusahaan diketahui berada pada kuadran I. Pilihan strategi yang terdapat pada kuadran I tersebut dapat digunakan untuk menunjang perkembangan unit bisnis dengan memertimbangkan kondisinya masing-masing. Berdasarkan pemetaan dengan menggunakan GE Matrix kondisi dua unit bisnis, yakni penyewaan properti untuk industri dan prima beton berada pada kuadran III (selektif) atau dalam kondisi rata-rata (average business) dan dua unit bisnis lainnya yakni pengelolaan air dan layanan logistik berada pada kuadran IV yang mengindikasikan kedua unit bisnis tersebut perlu mendapatkan perhatian khusus, karena memberikan kontribusi minim bagi perusahaan dengan kondisi bisnis yang terjadi saat ini.

\section{DAFTAR PUSTAKA}

Cooper, R.G., S.J. Edgett, \& E.J. Kleinschmidt. 2000. New problems, new solutions: making portfolio management more effective. Research Technology Management, 43(2): 18-33.

Iacob, M.E., D. Quartel, \& H. Jonkers. 2012. Capturing business strategy and value in enterprise architecture to support portfolio valuation. In Enterprise Distributed Object Computing Conference (EDOC), 2012 IEEE 16th International (pp. 11-20). IEEE.

Iswahyudi, D.M.P, Dwiatmanto, D.F. Azizah. (2016). Analisis Tingkat Kesehatan Perusahaan Berdasarkan Keputusan Menteri BUMN No. Kep-100/MBU/2002 (Studi Kasus pada Pabrik Gula Djatiroto, Lumajang Periode 2012-2014). Jurnal Administrasi Bisnis Vol.33 (1)
Kahveci, R., C. Meads. 2008. Analysis of strengths, weaknesses, opportunities, and threats in the development of a health technology assessment program in Turkey. International Journal of Technology Assessment in Health Care, 24(2): 235-240. doi:10.1017/ S026646230808032X.

Kawasan Berikat Nusantara. 2016. Annual Report PT. Kawasan Berikat Nusantara: Business Transformation. PT.KBN: Jakarta

Lukito, V.T., B. Lianto \& R.M. Surjani. 2013. Perancangan strategi bisnis di PT. Coronet Crown. Calyptra, 2(1): 1-19.

Mulyadi. 2009. Akuntansi Manajemen: Konsep, Manfaat, dan Rekayasa. Jakarta (ID): Penerbit Salemba Empat.

Piorita, D.P., A.H. Nasution \& A. Kunaifi. (2018). Pengembangan kriteria BUMN berbasis Balanced Scorecard. Jurnal Sains dan Seni ITS, 7(1): 8-11.

Pantjadhama, J.Y. 2015. Formulasi strategi berdasarkan analisa swot dan portofolio: Studi Kasus pada PT Semen Indonesia Tbk. Agora, 3(1): 245-254.

Priyanto, S., H. Suharno \& H. Haryono. (2016). Value Engineering dan Strategi Bisnis Pada PT Angkasa Pura II. Jurnal Manajemen Transportasi \& Logistik, 3(2): 245-257.

Sri Mulyani Jelaskan Penyebab Ekonomi Dunia 2017 Masih Lemah. 2018. https://ekbis. sindonews. com/read/1171949/33/sri-mulyani-jelaskan-pe-nyebab-ekonomi-dunia-2017masih-lemah-1484722757. Diakses 17 Januari 2018.

Sampor, A., L.M. Baga, B. Sanim. 2017. Strategi pengembangan portofolio produk investasi bank ABC. Jurnal Aplikasi Bisnis dan Manajemen, 3(3): 427-434. doi:10.17358/ jabm. 3.3.427.

Yuwono, S., E. Sukarno, M. Ichsan. (2007). Petunjuk Praktis Penyusunan Balanced Scorecard: Menuju Organisasi yang Berfokus pada Strategi. Jakarta (ID): PT Gramedia Pustaka Utama. 